\title{
Aoristo)))))
}

International Journal of Phenomenology, Hermeneutics and Metaphysics

\section{Heidegger and the Dialogue on Language}

\author{
Heidegger e o Diálogo sobre Linguagem
}

\author{
Prof. PhD. José Manuel Heleno \\ Universidade Católica de Lisboa - CEFI'
}

\begin{abstract}
Our aim is to think about the dialogue between a Japanese and a inquirer, entitled Aus einem Gespräch von der Sprache. Zwischen einem Japaner und einem Fragendem (1953-54). We try to argue that, although there is no philosophy of language in Martin Heidegger there is a powerful language design that marks the relationship with the being. Language becomes a saying that is an appropriation of what is given, that is, of what appears and becomes present. It is this relationship with the appearing that shows the power and mystery of language.
\end{abstract}

\section{KEYWORDS}

Being; Hermeneutics; Iki; Language; Metaphysics

\section{RESUMO}

O nosso intuito é pensar sobre o diálogo entre um japonês e um inquiridor intitulado Aus einem Gespräch von der Sprache. Zwischen einem Japaner und einem Fragendem (1953-54). Tentaremos argumentar que, embora não haja explicitamente uma filosofia da linguagem para Martin Heidegger, há um poder da linguagem que marca a relação com o ser. A linguagem torna-se uma forma de dizer que é uma apropriação do que é dado, ou seja, do que aparece e se torna presente. É esta relação com o aparecer que mostra o poder e o mistério da linguagem.

\section{PALAVRAS-CHAVE}

Ser; Hermenêutica; Iki; Linguagem; Metafísica

\footnotetext{
${ }^{1}$ E-mail: immheleno@gmail.com. Orcid: https://orcid.org/0000-0003-2272-1987
} 


\section{Aoristo)))))}

International Journal of Phenomenology, Hermeneutics and Metaphysics

The purpose of the following text is to think about Martin Heidegger's perspective on language, in particular the essay entitled "From a conversation about language between a Japanese and a inquirer" (Aus einem Gespräch von der Sprache. Zwischen einem Japaner und einem Fragendem), written in 1953-54 and which is part of the work entitled The Way to Language (Unterwegs zur Sprache). It is a fictional dialogue that is inspired by the meeting in Freiburg between Tezuka Tomio (19031983), a Japanese student of German literature, and Heidegger. Moreover, it is known that Heidegger's courses had been attended by Japanese students since at least 1921. The first student, Yamanouchi, attended Husserl and Heidegger classes in Freiburg 2 . Later, other students would follow, among whom Hajime Tanabe deserves reference for the relevance he will have in Japanese philosophy and for the way he made known to his countrymen the phenomenology of Heideggerian inspiration.

In addition, in the summer of 1946, Heidegger ventured into the translation of some chapters of Tao te King in the company of the Chinese scholar Paul Shih-yi Hsiao, which reaffirmed his interest in Eastern thought. A little later, in 1972, he even had discussions about the Chinese language with Chang Chung-Yuan, a widely recognized specialist in Taoism. Like many others, we are convinced that this tradition influenced the conceptions of the German philosopher. The following pages aim, to frame the dialogue text of 1953-54 (I), to outline the fundamental ideas of the author (II), and to present a critical view on the themes mentioned (III).

\section{THE DIALOGUE}

If we focus on the essay "From a conversation about language between a Japanese and a inquirer" 3 it is because it seems important to us to know how language plays a relevant role in the development of Heidegger's thinking. It is the author himself who states that from an early age his reflection on language and being determined the path of his thought.

We could say that philosophy of language is prominent if we think that it can assume the role of a first philosophy, because there are no metaphysical or ontological perspectives, epistemological or others without the starting of a language. Thus we could begin by stating that language both expresses thinking and shapes it; either it limits, misrepresents or expands, leaving to know if there is a kind of ideal language that would correctly translate thinking or if, adjusted to everyday language, could never achieve the purity that could be aspired to.

In the essay that we are commenting on, Heidegger tries to think about the relationships between what is or is not sayable/representable in the framework of

\footnotetext{
${ }^{2}$ We can read Tezuka's impressions in an account of his encounter with Heidegger in Carlo Saviani's essay EI Oriente de Heidegger (2004, p.153-160). Tezuka tells how Heidegger was interested in Zen thinking, not hiding his admiration for Daisetsu T. Suzuki, who most contributed to the Knowledge the West has about Zen Buddhism.

${ }^{3}$ English translation by Peter Hertz: "A Dialogue on Language between a Japanese and an Inquirer" (HEIDEGGER, 1971).
} 


\section{Aoristo)))))}

International Journal of Phenomenology, Hermeneutics and Metaphysics

metaphysics and fundamental ontology. One aspect that deserves our attention is that from German inquirers, such as Hamann, Herder and Humboldt, language is now being viewed from another perspective. These authors, each in their own way, modify the notion of language which is not considered as a mere tool of thought but rather as constitutive of reason. What is certain is that, even without mentioning them, Heidegger's perspective owes much to these inquirers. It is known how Hamann's famous text entitled "Metacriticism on the purism of reason" (1784) rethought Kant's notions of transcendental and a priori, being analyzed from language. Also Humboldt did not tire of showing that all language was an activity.

It is argued, in $\$ 34$ of Sein und Zeit, that the relationship of the Dasein with the world, in terms of affective disposition (Befindlichkeit) and understanding, is based on discourse (Rede). Thus, already in 1927 there was a clear understanding of the ontological importance of language, because it is it that allows to articulate the understandable and is the basis of interpretation and utterance. However, to see language as a tool capable of expressing something, as much as something based on propositions, is not to understand the essential, that is, that Dasein, because is thrown into the world, articulates in the form of meaning what is given to him. As Heidegger writes: "Definitively, philosophical research should decide to ask, once and for all, what is the way of being that suits language" (HEIDEGGER, 2006, p.166). It will be said that it is this way of being that further studies will clarify, even at the expense of a revision of certain assumptions developed in Sein und Zeit. There is, however, one certainty: that language is never a tool but has a constitutive character "by appeal to its world-disclosing function" (LAFONT, 2002, p.63).

It is, furthermore, in the context of Dasein's own facticity that both language and other ways of being of Dasein can be understood. It is worth, in this regard, to read the letter Heidegger wrote to Jaspers on June 27, 1922. Focusing on Jasper's latter book on Strindberg and Van Gogh, Heidegger states that the understanding of a disease takes place within the facticity of life, that is, it is done by taking into account the concepts and categories that structure the world where this disease (in this case schizophrenia) is situated. There is, therefore, already in 1922, the need to understand human existence in all its breadth, so that Heidegger writes to Jaspers: "The psychic is not something that man "has", "has" consciously or unconsciously, but something that he is and lives" (HEIDEGGER, JASPERS, 2003, p.24).

In "From a conversation about language between a Japanese and a inquirer" the concern with language a manifesto ${ }^{4}$. At the beginning of this dialogue Count Shuzo Kuki (1888-1941) recalled, particularly his notion of $I k i$, which had consequences in the understanding of Oriental art and poetry. Slipping into the notion of language and the danger that lurks the understanding of languages that have different

\footnotetext{
${ }^{4}$ Heinrich Wiegand Petzet, (2007, p. 217), states that "From a conversation about language between a Japanese and a inquirer" is one of Heidegger's lesser-known texts but one of those that the philosopher considered most important.
} 


\section{Aoristo)))))}

International Journal of Phenomenology, Hermeneutics and Metaphysics

essences, it is considered that the conversation between a Japanese and the one who interrogates (Heidegger himself), more than the difficulty due to what is spoken or the way in which one tries to do so, is rather due to the native language and the concomitant world of each of the interlocutors, which makes any dialog problematic. This happens because it is ingrained in the native language itself that the difficulties in understanding such distinct cultures are owed. And W. Humboldt, in his own way, had already said it. Like Cristina Lafont says (2002, p. 55), “Humboldt (defends) an account in which historical natural languages were considered as bearers of different worldviews".

According to the beginning of Heidegger's dialogue text any European language that was used to communicate (German, French or English) would have to account for $i k i$ - which, at the end of the dialogue, is clarified as the expression that indicates "grace and charm", something capable of showing the correlation between subject and object and is regarded as a "breath of silence in the shining attraction". However, I $k i$ is what no European language can translate, since its specificity does not allow it. Put in another way: the dialogue between Heidegger and a Japanese deals with the essence of language and the conviction that languages, rather than merely different, have a distinct essence. To think of the language of the East is to try to bring to that same language the concepts of the West and vice versa - which may make their understanding impossible.

Count Shuzo Kuki, pupil and admirer of Heidegger, is then the pretext to discuss this specificity of languages. Even if - as they say at some point in the dialogue - it is not strange for the Japanese that a conversation is indeterminate and does not fear that same indeterminacy. As Heinrich Petzet (2007, p.111) recalls, Kuki left for Paris to meet Sartre after leaving Germany. Moreover, It was the young Sartre who taught him French, and Count Kuki expressed his enthusiasm for Being and Time, authored by a "teacher under 40 years old", which led Sartre himself to discover Heidegger.

\section{FUNDAMENTAL ISSUES OF DIALOGUE}

If in "From a conversation about language between a Japanese and a inquirer" Heidegger is the one who seeks or interrogates, this indicates an essential aspect of the dialogue. The various testimonies about Heidegger's encounters with Japanese scholars or inquirers throughout his life show this facet of inquiring, curiosity, willingness to know what Eastern language and thought are like. By taking an interest in Taoism and Zen Buddhism, Heidegger wants his interlocutors to speak in Chinese or Japanese; he wants them to explain the characters, because it is important to grasp the way of being a language. Hence, the Orientals should be Oriental, according to what the philosopher says in many of his reflections, that is, instead of worrying about Western thought they should deepen the language and the world to which they belong to. It is said that Daisetsu T. Suzuki, in a meeting he had with Heidegger, asked him what he thought of Nishida Kitaró - Suzuki's personal friend and founder of the Kyoto school. Heidegger's response was to consider it "too 


\section{Aoristo)))))}

International Journal of Phenomenology, Hermeneutics and Metaphysics

western", as if Nishida, being busy with Western philosophers, used categories that were foreign to the eastern way of being that, precisely, that should be deepened.

Therefore, in the text we are commenting on, the fundamental question begins with: how do we understand different languages? Or: How is it possible to communicate or understand different worlds/languages? It is against this background that Heidegger speaks of his own philosophical path - the path he has been taking and the obstacles he has encountered. Following his reflection, Heidegger confesses that the question of language and being is fundamental. But the question remains: what is the essence of language? And can the Eastern language be encompassed in this essence? We must remember that, for Heidegger, the language is possible against the background of a shared world. The understanding of the world, the meaning, is the basis of dialogue for those who talk to one another.

What is certain is that Heidegger's criticism of an "aesthetic" removed from the creative act itself is a pretext for the philosopher to move away from Kuki's aspirations. Now, will these criticisms be founded? Died in 1941, Kuki probably never imagined that his former master could write a dialogue in which his name would appear. The structure of $I k i$, Kuki's text published in 1930, twenty-nine years before the dialogue that brought together a Japanese and an enquirer, took into account the conversations taken between the two. The fact that any language is rooted in a life-world is evident to Kuki himself in writing: "Our starting point must be the concrete that is given to us. What is given to us concretely is us. Also ethnicity as a globality of us. In this way, the existential condition of ethnicity [...] manifests itself with a certain meaning. Moreover, such particular meaning paves the way through the language" (KUKI, 2004, p. 255).

For Kuki it is the existential life of ethnicity that creates meaning and language, as expressly stated. Only then can the author go to the elucidation of the notion of $i k i$ by testing how this notion is translated into European languages and showing the relative failure to account for the Japanese expression. French chic and coquetterie, or other expressions, English or German, are some perspectives that only allow us to suspect the intensity and multiplicity of senses that $i k i$ conveys. Now, this is what his book seeks to defend and show, because it demonstrates both the dualist perspective that defines iki (as the tense character between man and woman that allows to understand the coquetterie), as the moral aspect, that is, the strength of soul that indicates a kind of resistance, as, finally, the renunciation or detachment, a kind of freedom and availability of the existing (AUROUX, 2019, p. 21-24).

We sign that it is the question of language and being that leads Heidegger, regarded as "the one who interrogates", to speak of his philosophical projects. From his concerns about Hölderlin's and Trakl's poetry, to the 1921 courses on "Expression and Appearance" to Being and Time, the intention is to show that being and language have always been issues that have troubled him. The famous expression of the Letter on Humanism that says that "language is the house of being" is the culmination of all these concerns. Let us remember that Karl Jaspers, on August 6, 1949, wrote to

$$
\begin{array}{r}
\text { José Manuel Heleno } \\
\text { Toledo, v. 4, n`2(2021) p. 219-229 }
\end{array}
$$




\section{Aoristo)))))}

International Journal of Phenomenology, Hermeneutics and Metaphysics

Heidegger and confessed that he regrets stumbling many times in the language used by him. Regarding the Letter on humanism and the expression "language as a house of being", it says that such enunciation resists its understanding. For Jaspers, language is just "a bridge." And he adds: "where is the language is not or is no longer being" (HEIDEGGER, JASPERS, 2003, p.144).

However, it is Heidegger himself who states that the greatest defect of Being and Time is probably that of having ventured too early in meditation on language and being. Moreover, the debate that takes place on the notion of hermeneutics indicates a way of thinking that seeks to clarify the being and language - a pretext for Heidegger to openly refer to the theological origin of the path that was unfolding.

Then the subject that follows in the dialogue is to know what hermeneutics is for Heidegger. He claims that he used the term for the first time in 1923, at a conference. The word hermeneutics then indicates the new direction of phenomenology. And the insistence that "From a conversation about language between a Japanese and a inquirer" refers to the explicitness of its meaning, it is due to the fact that its "mystery" is in knowing what it is to interpret. The important thing, that moves Heidegger, is to know what "is the essence of interpretation from hermeneutics". Once again, and according to the rhythm that the all dialogue goes through, is about what it originates - and we realize that we move from the essence of language to the essence of interpretation, precisely in the context of the relationship between language and being.

However, everything seems to indicate that one cannot think about the relationship between language and being without referring to metaphysics. For example: what is metaphysical or not in eastern saying/thinking? If metaphysics starts from a distinction between the real and the ideal, to what extent is this distinction present in Eastern art and poetry? The $i k i$ was precisely the notion which tested such distinction. Now, we will not understand $i k i$ unless we are beyond this distinction. Better: in everything that can be said about this notion, there is more than a mere distinction between real and ideal, sensitive and non sensitive. Wanting to understand $i k i$ from Western categories is not to understand it at all.

On several occasions Heidegger's form of philosophy takes on a language that seems to repudiate logic to venture into other forms of expression. And it is undeniable that one of the greatest charms of his language - but, for others, one of his greatest weaknesses - comes from these circles so often mentioned that there are other ways of assuming what is indeterminate in any language and, as if it were a miracle, is able to give, to see what appears. Indeed, Heidegger clearly assumes the consubstantial indeterminacy of thought, as if another way of thinking, like fundamental ontology - which he asks for the meaning of being - he had already foreseen. That is why all people, who think, end up assuming the indeterminate, as it is, moreover, visible in the very notion of $i k i$.

It is there, in this appeal to the supra-sensible, that we are both referred to metaphysics and to something indefinable or indeterminable that makes the essence of the creative act. More than the notion of representation, obsessed with the design of a way of being objective, what matters is something difficult to think that 


\section{Aoristo)))))}

International Journal of Phenomenology, Hermeneutics and Metaphysics

deliberately retreats into indeterminacy. This is how language itself, far from being the mere relationship between phonemes and graphemes, on the one hand, and meanings, on the other, has gestures and beckons that seem to say more about the way of being of language than the phonemes themselves.

The No Theater also serves as a pretext to think about metaphysics. And for the first time in "From a conversation about language between a Japanese and a inquirer", the notion of emptiness appears. The stage of the No Theater is empty, because this is the only way to show its intentions. In this regard, the example of the mountain will eventually be given: how to raise one hand and, by keeping it still above the eyes, at the height of the eyebrows, let a mountain "appear", as if collecting it in that same gesture by bringing it to you. Hence "gebärde ist Versammlung eines tragens", that is, "the gesture is the recollection of a bring".

Now, the conundrum of the gesture is what brings us to the mountain. When it appears in the void, the mountain is given by the gesture it marks. He's the one who brings you to the mountain, letting it appear. Thus, if metaphysics sees language as a relationship between something sensitive and non-sensitive - as the notion of sign indicates - there is now another dimension of language that is able to show the collecting and signaling/gesturing of the language itself. If language is initially referred to a metaphysical model, it is currently a question of thinking differently. As if the word, sensitive and real, referred to a non-sensitive, ideal being - proper to metaphysics to differentiate real and ideal. It is in this framework that one can understand hermeneutics not so much as an art of interpretation, but precisely as what it is capable of announcing or bringing, making something known.

In the 1929 Heidegger's essay, What is Metaphysics, when translated into Japanese the following year, it was shown that the nothing, far from being interpreted in a nihilistic way, should be otherwise - which led Heidegger to praise the translation of the Japanese student who had attended his course. Emptiness is being; it is language itself that can lead us to this notion of emptiness; that collects and brings to itself the various elements. This emptiness is the being, and not merely the being of the entity. We're beyond metaphysics. And what we did, did not destroy that metaphysics. Rather, it is an "original appropriation of its history". And it is up to the language to show this original appropriation i.e. the way the language says/thinks, this being/nothing. Only a free gesture can provide this.

\section{CRITICAL PERSPECTIVE}

There is no philosophy of language in Heidegger if we understand such a systematization of views on language. It is significant, for example, that the Dictionnaire Heidegger (VAYSSE, 2007) has no input regarding "language". But the fact that it does not exist must be understood in the context of the fundamental ontology defended by the author, because it would be a contradiction if such philosophy existed out of his need to question the meaning of being. The way he refused a philosophy of language is justified in the context of his hermeneutic and

$$
\begin{array}{r}
\text { José Manuel Heleno } \\
\text { Toledo, v. 4, n² (2021) p. 219-229 }
\end{array}
$$




\section{Aoristo)))))}

International Journal of Phenomenology, Hermeneutics and Metaphysics

phenomenological perspective that the 1953-54 dialogue shows. Furthermore, we may say that the Kehre must be understood as a linguistic turn. If the fundamental of Being and Time remains, the turning point of Heidegger's philosophy pays attention to language.

Wayne D. Owens, in "Heidegger and the philosophy of language" (1978), shows that a philosophy of language aims to form a theory trying to objectify the theme of his study - the language itself. It does so by architecting a kind of metalanguage where fundamental concepts can account for this same theory are highlighted. Heidegger was skeptical of this type of philosophies, because the fundamental thing is not to form a theory of language. If what we have just mentioned can be challenged due to the repeated way as Heidegger, in "From a conversation about language between a Japanese and a inquirer" uses the term essence (Wesen), as if seeking precisely a theory and a way of objectifying language trying to form a rigorous representation of it, this should not be, it seems to us, the interpretation of its intention.

By seeking an essence, Heidegger not only seeks to know what language is but he also pursues what language itself cannot express, as if the language, presents to itself, always is an excess of itself. This is its "essence", this saying that it exceeds and that constitutes, precisely, the miracle of language. In fact, Heidegger shows that expressions such as "subjectivity", "lively", "consciousness" and so many others convey a form of thought that deserves to be rethought. So to think otherwise is to rethink one's own language, precisely what it conveys and hides. If we think about the usual representations, the way we express ourselves, we understand that it is necessary to appeal to another way of saying. And we do it because what is shown (the phenomenon) ends up showing that it is hidden when showing itself. What comes to the presence in the phenomenal appearance deserves our attention because man, when relating to this appearance, wants to interpret it - and it is this relationship that Heidegger calls hermeneutics. When, at the end of the dialogue, one speaks in the Saga (Die Sage) the intention is, it seems to us, to draw attention to this saying that is always beyond saying, which shows the power of language, that is, of its saying, "more original than all that is said" (HEIDEGGER, 1976, p.133).

In 1930, in Bremen, after a conference entitled "From the essence of truth" (which was only to be published in 1943), Heidegger met some of the participants at the home of a merchant named Kellner informally. On the pretext of a question that was unforeseen, namely whether or not it was possible to put ourselves in the place of another human being and understand him, Heidegger asked Kellner, unexpectedly, the book Parables, by Chuang-Tse, which had been translated by Buber. He then read the allegory to the fish and "captivated all gifts" (PETZET, 2007, p.32).

It is a story in which Chuang Tse and Huí Tse strolled over the Hao River Bridge. As Chuang Tse makes a reference to fish and their happiness when they see the surface, the caller asks him how he can know if they are happy if he, Chuang Tse, is not a fish. This one replies, "As you are not me, how can you know that I do not know what the happiness of a fish is?" However, if Huí Tse admits that he cannot 


\section{Aoristo)))))}

\section{International Journal of Phenomenology, Hermeneutics and Metaphysics}

really know it, he can, however, state that there is no doubt that Chuang Tse is not a fish. So, to be "consistent you have to conclude that you can't know what a fish's happiness is." Finally, Chuang Tse's reply is the following: "I ask you then to return to the starting point. He asked me, «How can you know what a fish's happiness is? » What you said, since you had already know that I knew it and so you asked me, confirms that I knew it when I was on Hao" (CHUANG TSE, 2017, p.52-53).

This allegory speaks of the paradoxes of understanding the other and the difficulties in communicating ${ }^{5}$. A hypothetical explanation is that we have a kind of intuitive knowledge of what the world might be, that is, Chuang Tse's starting point is that he and Huí Tse walk over a bridge and immediately share a series of intuitions about what is appearing (these recalls the Heidegger's notions of life-world and facticity). If it is difficult to argue how Chuang Tse knows what the happiness of a fish is. However, the fact that he says it and his interlocutor understands shows something intuitive and directly shared. This may be one of the possible explanations for the allegory. And it is the allegory who refers to us, after all, the essence of language and the languages and the ways of being in the West and in the East. Apparently, there can intuitively be anything shared by the interlocutors, a bit like the translation of Tao te King sowed that there was a common intuition between Heidegger and Paul Shih-yi Hsiao.

When the questioner asks the Japanese how to say "language" in his language, he states Koto $b a$. Ba as flowering; as the leaves of flowering or petals. And koto the "happening of the lightening message of the graciousness that brings forth" (HEIDEGGER, 1971, p.47). Thus, language is like "petals that stem koto". True to his design, Heidegger does not want to be caught in the meshes of representation, that is, in the desire to transform everything into concepts, representations or objects. Koto $b a$, the language, points out the strength of what happens, as if the mystery of language consisted in the flourishing of an event. Language is what allows the appropriation of what happens. And it is this power that Heidegger shows how far away he is from the notions of representation. By making signs (des Winkens) language shows what is given and what is hidden in this saying - hence its power and this mystery that is embodied in the relationship between man and the world.

Thus, when focusing on "From a conversation about language between a Japanese and a inquirer" it is necessary to respond to the movement (to the rhythm) of the concepts that the conversation makes happen. From the essence of language we are referred to one's own indeterminacy and even silence, that is, from the beginning to the end of dialogue, indeterminacy is welcomed, not because of argumentative insufficiency but, instead, because it is necessary to think differently

\footnotetext{
${ }^{5}$ The other story quoted by Petzet (2007, p.83) about Chuang Tse, also in Bremen, but now concerning the celebration of Heidegger's seventy years, has to do with a text that Heidegger advised as a reading for the seminar he would give in that city on "Image and Word". It is a story about a carpenter and the creation of a support for bells that shows what can be understood by creation (of an artifact; of a work of art). Cf., Chuang Tse (2017, p. 127-128).
} 


\section{Aoristo)))))}

International Journal of Phenomenology, Hermeneutics and Metaphysics

so that anything like the essence of language can emerge. This presumes interpretation, freedom and the ability to peers into the essentials.

We understand that the whole dialogue takes on another thinking dimension, which some may refuse under the pretext of having conceptual deficiencies. But it is this conceptual argumentation, this rationality, or this logic transformed into calculus that is systematically rejected by Heidegger, Indeed, if the mode of conceptual argumentation is easily nested in all human experience, such is regrettable. If the mode of metaphysical representation seems inevitable, Heidegger will then have to shift his inquiry to another level. It is not already phonemes and graphemes, but beckon and gestures. As we have mentioned before, the word is beckon and not merely sign (simple designation).

If the notion of hermeneutics is referred several times in the follow-up of the conversation, it is to fit it in the phenomenological perspective. By assuming the indeterminacy of dialogue it is assumed that hermeneutics is a message capable of showing duplicity, "because what matters is to see appearance as the reality of presence in its essential origin" (HEIDEGGER, 1971, p.40). The difficult task of language would be not so much to show, for example, the interior of a subject, that is, the way it is expressed, but the Saying himself. One of the oldest misconceptions in the history of metaphysics is to start from the self as a subject. Now on we must start with being and language in its mutual fulguration.

\section{REFERENCES}

AUROUX, S. (dir.). La pensée japonaise. Paris: Puf, 2019.

CHUANG TSE. Trad. António Miguel de Campos. Lisboa: Relógio D’Água Editores, 2017. HEIDEGGER, M. Acheminent vers la parole. Paris: Gallimard, 1976. 1971.

. On the Way to Language. Translated by Peter Hertz. New York: Harper \& Row, Publishers,

Unterwegs zur Sprache. Frankfurt am Main: Vittorio Klostermann, 1985.

A caminho da linguagem. Tradução portuguesa por Marcia S. P. Schuback, Petrópolis: Editora Vozes, 2003.

HEIDEGGER, M./JASPERS, K., Correspondencia (1920-1963). Edición de W. Biemel y H. Saner, Madrid: Editorial Sintesis, 2003.

Sein und Zeit. Tübingen: Max Niemeyer Verlag, 2006.

LAFONT, Cristina. The Linguistic turn in Hermeneutics Philosophy. Cambridge/London: The MIT Press, 2002.

KUKI, S. La Estructura del Iki, Coordenação de Alfonso Falero, AnMal, XXVII, 1, pp. 247-269, 2004.

NETO, A. Florentino. "Receção e Diálogo - Heidegger e a filosofia japonesa contemporânea",

Natureza Humana 10 (1): 147-160, jan.-jun, 2008.

PETZET, H. W., Encuentros y diálogos con Martin Heidegger, 1929-1976, Buenos Aires: Katz Editores, 2007.

SAVIANI, C. El Oriente de Heidegger. Barcelona: Herder, 2004.

VAYSSE, J.-M. (dir.). Dictionnaire Heidegger. Paris: ellipses, 2007.

WAYNE D. Owens. "Heidegger and the philosophy of language", Auslegung, Vol. XIV, no 1, pp. 49-66, 1987. 


\section{Aoristo())))}

International Journal of Phenomenology, Hermeneutics and Metaphysics

Submitted: June 16, 2021

Accepted: July 08, 2021 